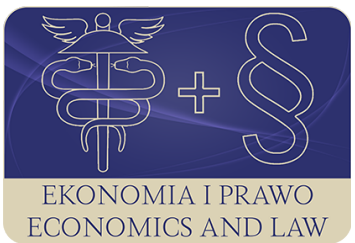

EKONOMIA I PRAWO. ECONOMICS AND LAW

Volume 19, Issue 2, June 2020

p-ISSN 1898-2255, e-ISSN 2392-1625

www.economicsandlaw.pl

EKONOMIA I PRAWO
ECONOMICS AND LAW

ORIGINAL ARTICLE

received 30.03.2019; revised 03.01.2020; accepted 30.06.2020

Citation: Wiśniewski, A. (2020). Competitiveness of sports market enterprises: determinants, classification, challenges. Ekonomia i Prawo. Economics and Law, 19(2): 367-377.

doi:10.12775/EiP.2020.025.

\title{
Competitiveness of sports market enterprises: determinants, classification, challenges
}

\author{
ADAM WIŚNIEWSKI \\ University of Warmia and Mazury in Olsztyn, Faculty of Economic Sciences, Institute \\ of Management and Quality Sciences, ul. Prawocheńskiego 3, 10-720 Olsztyn, Poland \\ $\square$ adam.wisniewski@uwm.edu.pl \\ (D) orcid.org/0000-0003-0395-9308
}

\begin{abstract}
Motivation: Over recent years, dynamic development of new sectors and industries has been observed. As research conducted in 2004 shows in the entire European Union, sport generated 407 billion EUR of value added, which is 3.7\% of GDP of the entire EU. At the same time, it generated 15 million jobs, which is $5.4 \%$ across the EU. According to the Report of the Ministry of Sport and Tourism presented in 2010 named Rachunek Satelitarny Sportu dla Polski, in the 2006 in Poland, the total value of demand for sports goods and services was PLN 20.7 billion. This is equivalent to the share of GDP in total Polish GDP in 2006 at 1.96\%. Increasing the number of entities on the sports goods and services market mainly on the supply side resulted in increased competition and the need to devote their attention to elements related to competitiveness.

Aim: This paper aims to present the main determinants, analyze and attempts to classify sports market entities in team-played disciplines. The study included subjects competing in the field of volleyball.

Results: As a result of the study, conclusions regarding the manner of their rivalry and the instruments of competition used for this purpose were presented. A group of factors shaping a competitive position was listed. One of the major conclusions was statement that clubs competitive position can only be measured in terms of sport results. This is due to the fact that there are different priorities in shaping the budget. Part of the sport entities may focus on maximizing the budget while some maximize profit. The paper is the starting point for further research on competitiveness on the sports market to be gradually extended by further disciplines.
\end{abstract}


Keywords: competitiveness; management; sports clubs; determinants

JEL: D20; L83; L19

\section{Introduction}

Observing the development of the economy in its activities from the recreational and amateur category, professional units and disciplines have been specified. Sport also plays a role in regional economic development (Green, 2001, pp. 1-20). The concentration on the economic aspects of the functioning of sports organizations has caused the business orientation of managers and sports clubs. As a result, professional leagues were established at the professional level with the use of properties so-far characteristic of the so-called classic business. Research has shown that in 2004, in the European Union, broadly understood sport generated EUR 407 billion of added value, which is 3.7\% of GDP of the entire EU. At the same time, it resulted in 15 million jobs, which is 5.4\% of the entire labor market in the European Union (Dimitrov et al., 2006, p. 13). In Poland, the sports market has also been transformed into a significant element of the country's economy, as the total value of services and sports products in 2006 amounted to PLN 20.7 billion, equivalent to 1.96\% of GDP.

The context of competitiveness of sports clubs presented in this way allows us to define in this study the objective to determine the determinants and classifications of individuals in the volleyball industry in Poland. In the following sections, a review of the literature related to the described issue will be presented, the methodology of the conducted proceedings, the characteristics of the industry, the results of the research, competitiveness determinants of volleyball clubs and further challenges.

The paper aims to identify the determinants of sports club's competitiveness determinants and classification. Another aim is to point out challenges in everyday management and organizational functioning of this entities. In relation with those aims there were set research questions: Which elements determine the competitive position and place in classification of a sports club? What challenges do those clubs face in everyday business and sport practice? What opportunities they have to improve their position?

In the research there was used method of secondary data analysis focused on international and domestic regulations regarding functioning and competitiveness of sport companies in volleyball major league (PlusLiga). Also there was used the method of survey questionnaire submitted personally to club representatives or its' CEO. The study was addressed to volleyball clubs from PlusLiga. Time range of the research was sport season of 2017/2018.

\section{Literature review}

The economic dimension of sport has resulted in the emergence of more units participating in this market. As a result, the competitiveness of clubs, suppliers 
of resources and complementary sports events has increased. In a natural way, this development makes it necessary to look for solutions that allow to overtake and gain an advantage over competitors. In practice, the development of concepts that build data from sport management practices is important for the development of the sports industry (Chalip, 2006; Doherty, 2013; Fahlen \& Stenling, 2018 , p. 2). The sole sustainable source of competitive advantage is the ability to learn faster than competitors (Senge, 2012, p. 25). However, the social aspect is also extremely important. Clubs are also responsible for creating a secure internal environment. In the first place, they should focus on fulfilling social obligations that affect the environment rather than using limited resources for strictly business purposes (Robertson et al., 2019, p 3). Competitive balance is important in sports leagues, primarily from an economic and managerial point of view (Leeds \& von Allmen, 2004, pp. 361-366).

The adoption of such a cause - and - effect chain allows us to take the concept of the sports industry. According to Waśkowski (2012, p. 5), it is composed of people, sports institutions, commercial enterprises, media and sports clubs (table 1).

The main segment of the sports industry are sports clubs (Waśkowski, 2012, p. 5). In addition to striving to achieve the best sports results, they are currently focused on creating the highest market value of the offered products, which leads to obtaining funds for maintaining the position and further development. Around the clubs there are four segments 'complementing' the activity of sports clubs. Sports institutions are defined as entities that organize and manage professional sports competitions, international and national federations. Their main goal is to coordinate, supervise and support the development of clubs and athletes. People are primarily athletes, managers, advisers and collaborators of athletes and clubs. Commercial enterprises operate to provide direct financial benefits related to cooperation with sport. These are therefore suppliers of sports equipment, nutrients, medical services and accessories, sponsors, advertisers, licensees and consulting companies. Some of them benefit from the use of the sports club brand, while others earn a profit from providing products and services necessary for the club's operation. Media cooperation is a natural stage in the development of professional sport. They provide coverage and broadcasts from a sports spectacle, specialize in sports or provide a platform for the exchange of information related to sport. Economic benefits occur due to the acquisition of advertisers during the broadcasting of information or broadcast about the show / club, the number of page views, the commission for access to information or the provision of licenses to other media entities. The sports industry presented in this way clearly describes the background of the functioning of sports clubs, which is an important point to analyze the determinants of their competitiveness.

The definition of competitiveness was comprehensively defined in the 1994 Global Competitiveness Report, which defined it as 'the ability to create more wealth than competitors' (World Economic Forum, 1994, p. 18). One of the more 
popular definitions of competitiveness is the explanation provided by Stankiewicz (2005, p. 19), who stated that it is 'a phenomenon in which participants undertake rivalry in pursuit of similar goals, which means that actions undertaken by some to achieve specific goals make it difficult or impossible to achieve the same goals by others'.

Additional elements important from the point of view of this work are determination of the competitive position and instruments or determinants of competition. The competitive position is defined as a multidimensional category resulting from a number of factors, e.g. market share, market impact, scale of operations, skills and adaptability or dominance in the market segment (Garbarski, 1997, p. 38). On the other hand, the instruments of competition are elements and tools used to gain buyers' interest and to overtake other companies in this matter. Nimakorn et al. (2013, pp. 45-49) identified the determinants of the effectiveness of the operation of the subject of the female volleyball league in Thailand. Among them, they mentioned the competences of the staff, club's finances, relations with the media, the image, the structure of sponsors and the expectations of the fans.

The impact on the competitiveness of sports clubs has a number of conditions depending on time, the specificity of the discipline and the economic situation of the country in which they operate. Comprehensively they were described in the so-called the competitiveness diamond (Porter, 1990, p. 127).

Diamond model of Porter describes environmental elements that facilitate or hinder building a company's competitive advantage (scheme 1). The assumption is a situation where there are as many factors as possible conducive to the progress of development conditions. The model has four determinants of competitive advantage and two factors of influence (chance and government regulations). The element factors conditions result from the distribution and the way they are used. The level of organization's advancement affects their importance. Basic factors (natural resources, capital) or advanced (developmental research) may occur. The second element is the degree of specialization (general or specialized). Depending on the combination of factors, there may be a competitive advantage of different durability and importance. The best is to achieve a combination of advanced and specialized factors.

The demand conditions element manifests itself in the diversity and nature of the needs of buyers. The characteristic elements are, among others, the growth rate and the size of demand, the occurrence of demanding buyers, the transfer of domestic demand to foreign markets and the anticipatory needs of customers.

Competitive advantage depends also on the level of development of a given market and location of the so-called accompanying and supporting industries. Thanks to this, effective and quick access to raw materials is possible, as well as the ability to react quickly or stimulate innovation. The closeness of the cooperating units and their similarity favors the flow of information, capital and ideas influencing the development and achievement of competitive advantage. 
The last dimension is firm strategy, structure and rivalry. The way of functioning, the adopted strategy and the nature of competition affect the way and durability of competitive advantage. The correct adjustment to the market specificity stimulates the further development of the organization. Rivalry, its degree and character also determine the way new enterprises appear. It effects on the entrance barriers. The low level of competition weakens the organization's innovation.

Opportunities favor the possibility of making changes. They result from the environment. They enforce the quality of the company's operation and create conditions for taking advantage of opportunities. Governmental constraints are related to the creation of a framework for functioning and supporting activities. They create the context of the creation and competition of enterprises. They affect the goals and motives of the proceedings and the nature of competition.

\section{Methods}

In the research there was used method of secondary data analysis focused on international and domestic regulations regarding functioning and competitiveness of sport companies in volleyball major league (PlusLiga). Also there was used the method of interview and survey questionnaire submitted personally to club representatives or its' CEO. The study was addressed to volleyball clubs from PlusLiga. As a result, from 16 clubs that was on this sport level at the time, from this group there were 4 clubs that consent for the survey.

The research was aimed at creating a catalog of determinants of the competitiveness of the sports club, as well as verification and validation of Porter's diamond used and scoped to the sport market. The implementation of these assumptions gives a picture of the functioning of a sports club and allows for practical application in clubs. This allows you to increase your chances of achieving market success. The limitation of the presented procedure is the necessity to adjust some of the areas specific to a given sport. Therefore, certain universalism is limited to a certain degree. In the case of an attempt to undertake further research, it will be necessary to take into account the characteristics of another discipline on which the research presented in this paper will be translated.

\section{Results}

The results are innovative in the scale of polish sports sector, especially in the area of volleyball discipline. As a result of the research conducted on a sample of 4 volleyball clubs appearing at the highest level in Poland (PlusLiga), in the first stage the specificity of the market was verified based on the assumptions presented in the above considerations. To this end, Porter's diamond was used, which was transferred to the sports industry; volleyball. The concept has been scoped and used indirectly to describe the conditions of the units. Below are the areas indicated by the representatives of volleyball clubs (table 2). 
Complementary elements are Chance and Government. They were identified and characterized in table 3.

As can be seen from the table 3, most of the opportunities indicated by the respondents focus on the conditions leading to the acquisition of new sources of funding or the increase in the popularity of the club (new players, participation in international competitions). This is due to a possible increase in the reputation of the club and, consequently, an opportunity to generate new sources of financing. An important opinion of respondents is also internationalization, which is confirmed by other studies focusing on the competitiveness of sports clubs. The elements that require attention and development include, inter alia, personnel servicing foreign relations and intermediary in this contact, after-sales and support services (Zhao \& Zhu, 2015, p. 111). During the research one of the determinants was stated as the main priority of a sport club that is budget strategy. In a sport industry there are two different approaches. One aim to build maximal profit from the season budget, other choose to maximization the budget. Second strategy allows to build bigger annual or season budget. From it there is a chance to buy or contract better players who have bigger salary expectations. As a result of the research all of the clubs described their strategy as budget maximization. The profit at the end of season is a secondary priority. Also, the element of competition and risk taking is common to all units. This is in line with the view of the team of authors who presented archetypes of participants of the sports market in relation to mountain bike discipline. As dimensions, as an element interesting from the point of view of this work, they indicated competitiveness and risk taking (McEwan et al., 2018, p. 12).

In the examined period sports clubs are subject to relatively restrictive requirements originating primarily from the organizer of the competition. In addition to universal regulations directly related to the functioning of the company, they must provide a budget for the competition season guaranteeing the implementation of the entire competition, having contracts with players composing the required personal composition, and having a sports hall to conduct sports competitions. In the current sports system of volleyball, there is the possibility of getting a sports promotion to the highest class and dropping it to the lower level games. This element was indicated by the respondents as a potential risk factor and its removal - i.e. 'closing the league' is an opportunity for safe functioning and stable development.

Based on the above information, a catalog of determinants of the competitiveness of the sports club was created; the quality of the show, the quality and breadth of the offer, the reputation of players and members of the training staff, the convenience of payment terms and offer price, club brand, promotion forms, the possibility of adapting the offer to customer expectations, innovation, scope of additional services, cost advantage, availability and selection of suppliers. 


\section{Conclusion}

Participation in professional sports competitions is associated with risk. This risk accompanies the daily functioning of the sports club. At the same time, there is a tendency to seek solutions aimed at risk reduction. The determinants of competitiveness presented by the respondents and the specificity based on the concept of Porter's diamond scope present a picture of sport units seeking to compete in a cooperative manner, avoiding the rivalry of 'burnt land'. Due to the regulated and almost completely closed nature of the market, volleyball clubs compete for geographically focused customers. The presented classification of competitiveness determinants allows to put a few questions important from the point of view of further research. First of all, what motivates sports clubs to develop, created opportunities or restrictions set by market regulators? Which model of functioning is the most effective when using the determinants presented? What is the most durable area of competitive advantage possible for a sports club to achieve? Answering these questions in further research will allow us to get closer to getting a full picture of the functioning of the sports industry and translating the presented research into the economic practice of clubs.

This paper presents the concept of determinants of the competitiveness of a sports club. Starting from theoretical considerations on the specificity of the market and competitiveness, the decision was made to base empirical research on the Porter diamond model, useful not only from the international perspective but also from the local functioning of the sports club. The assumptions made have been postponed to the ground of volleyball clubs. In empirical studies, which included four volleyball clubs selected in a targeted way, the theoretical sets of determinants were verified. Respondents made gradation and evaluation of factors grouped according to theoretical assumptions. Table 1 and 2 present the essence of research results presenting the classification of competitiveness factors of a sports club. The examined elements allow to get a picture of club functioning. One of the major conclusions was statement that clubs competitive position can only be measured in terms of sport results. This is due to the fact that there are different priorities in shaping the budget. From the perspective of their current operations, the elements presented as regulations rather than potential opportunities seem to be more important. This is confirmed in the area of indicated related and supporting industries, a large number of which significantly determines the success of projects.

Shown results are unique in the country and international scale. Author during the research didn't find any other similar research papers focused on the volleyball discipline. In the general scope of global sport there are few that focus on the competitiveness, but they aren't conducted with the use of tools engaged in this paper. Therefore, it can be said that this paper results are unique in global scale. 
The results create background for further research of competitiveness of sport clubs. The used survey is flexible and universal that allows to use it for other sport disciplines.

Further research based on this study will seek to determine the sustainability of competitive advantage and to estimate the competitiveness balance resulting from the combination of mandatory regulatory requirements and determinants of competitive rivalry. This work is a starting point for future studies of sports organization management and an impulse for discussion on the condition of clubs.

\section{References}

Chalip, L. (2006). Toward a distinctive sport management discipline. Journal of Sport Management, 20(1). doi:10.1123/jsm.20.1.1.

Dimitrov, D., Helmenstein, C., Kleissner, C., Moser, B., \& Schindler, J. (2006). Die makrö̈konomischen effekte des sports in Europa. Retrieved 02.01.2020 from http://www.sportministerium.at.

Doherty, A. (2013). Investing in sport management: the value of good theory. Sport Management Review, 16(1). doi:10.1016/j.smr.2011.12.006.

Fahlen, J., \& Stenling, C, (2018). (Re)conceptualizing institutional change in sport management contexts: the unintended consequences of sport organizations' everyday organizational life. European Sport Management Quarterly, 19(2). doi:10.1080/16184742.2018.1516795.

Garbarski, L., (1997). Wybór rynku docelowego przez przedsiębiorstwa w warunkach konkurencji. In K. Zbytniewska (Ed.), Marketing jako czynnik $i$ instrument konkurencji. Warszawa: SGH.

Green, B.C. (2001). Leveraging subculture and identity to promote sport events. Sport Management Review, 4(1). doi:10.1016/S1441-3523(01)70067-8.

Leeds, M., \& von Allmen, P. (2004). The economics of sports. Boston: Addison-Wesley.

McEwan, K., Weston, N., \& Gorczynski, P. (2018). Differentiating identities within an extreme sport: a case study of mountain biking print advertisements. Frontiers in Psychology, 9. doi:10.3389/fpsyg.2018.01668.

Nimakorn, C., Samahito, S., \& Kutinatara, I. (2013). A business model development for a professional women's volleyball league in Thailand. ABAC Journal, 33(1).

Porter, M.E. (1990). The competitive advantage of nations. London: Macmillan.

Robertson, J., Eime, R., \& Westerbeek, H. (2019). Community sports clubs: are they only about playing sport, or do they have broader health promotion and social responsibilities? Annals of Leisure Research, 22(2). doi:10.1080/11 745398.2018.1430598.

Senge, P.M. (2012). Piąta dyscyplina. Warszawa: Wolters Kluwer.

Stankiewicz, M.J. (2005). Konkurencyjność przedsiębiorstwa: budowanie konkurencyjności przedsiębiorstwa w warunkach globalizacji. Toruń: TNOiK. 
Waśkowski, Z. (2012). Instytucjonalna struktura biznesu sportowego: ujęcie modelowe. Zeszyty Naukowe Uniwersytetu Ekonomicznego w Poznaniu, 220.

World Economic Forum. (1994). Global competitiveness report 1994. Retrieved 02.01.2020 from https://www.weforum.org.

Zhao, Y., \& Zhu, L. (2015). Research on the Chinese sport industry and related policy guided beneficial pattern: theoretical analysis and novel perspective. In L. Liu, \& J. Shi (Eds.), Proceedings of the Ist International Symposium on Social Science. Wuhan: Atlantis Press. doi:10.2991/isss-15.2015.27.

\section{Acknowledgements}

Author contributions: author has given an approval to the final version of the article.

Funding: this research was funded by the Department of Organization and Management, Faculty of Economic Sciences, University of Warmia and Mazury in Olsztyn sources.

Note: the results of this study were presented at 10th International Conference on Applied Economics Contemporary Issues in Economy (June 27-28, 2019, Torun, Poland). 


\section{Appendix}

Table 1.

The subjective structure of the sports industry

\begin{tabular}{|c|c|c|c|}
\hline People & Sport institutions & Commercial enterprises & Media \\
\hline $\begin{array}{l}\text { people from the immediate } \\
\text { surroundings of athletes }\end{array}$ & $\begin{array}{c}\text { organizers and entities managing } \\
\text { professional sport }\end{array}$ & $\begin{array}{l}\text { licensee, specialized } \\
\text { consulting companies }\end{array}$ & $\begin{array}{l}\text { modern digital } \\
\text { media }\end{array}$ \\
\hline managers, agents, advisors & $\begin{array}{l}\text { sport international organizations, } \\
\text { Comité International Olympique }\end{array}$ & sponsors & sports media \\
\hline \multirow[t]{2}{*}{ athletes } & national sports organizations & $\begin{array}{l}\text { suppliers of sports } \\
\text { equipment }\end{array}$ & $\begin{array}{l}\text { media broadcasting } \\
\text { sports spectacles }\end{array}$ \\
\hline & sports clubs & & \\
\hline
\end{tabular}

Source: Waśkowski (2012).

Table 2.

\section{Diamond determinants of a volleyball clubs}

\begin{tabular}{|c|c|c|c|c|c|}
\hline \multirow[b]{2}{*}{ Dimensions } & \multicolumn{2}{|c|}{ Factor conditions } & \multirow{2}{*}{$\begin{array}{l}\text { Firm strategy, } \\
\text { structure } \\
\text { and rivalry } \\
\end{array}$} & \multirow{2}{*}{$\begin{array}{l}\text { Demand } \\
\text { conditions }\end{array}$} & \multirow{2}{*}{$\begin{array}{l}\text { Related and supporting } \\
\text { industries }\end{array}$} \\
\hline & $\begin{array}{c}\text { Level } \\
\text { of advancement }\end{array}$ & $\begin{array}{c}\text { Degree } \\
\text { of specialization }\end{array}$ & & & \\
\hline elements & $\begin{array}{l}\text { - basic factors: } \\
\text { sports hall, } \\
\text { office, sports } \\
\text { support } \\
\text { resources, } \\
\text { technical } \\
\text { support } \\
\text { resources } \\
\text { - advanced } \\
\text { factors: train- } \\
\text { ing skills, } \\
\text { the ability } \\
\text { to acquire } \\
\text { players }\end{array}$ & $\begin{array}{l}\text { - general fac- } \\
\text { tors: related } \\
\text { to the current } \\
\text { functioning } \\
\text { of the club } \\
\text { - specialized } \\
\text { factors: } \\
\text { specialization } \\
\text { of spectacle } \\
\text { organization, } \\
\text { logistics } \\
\text { solutions re- } \\
\text { lated to trips } \\
\text { to matches, } \\
\text { cost optimi- } \\
\text { zation }\end{array}$ & $\begin{array}{l}\text { cooperation } \\
\text { rivalry, strat- } \\
\text { egy of budget } \\
\text { optimization } \\
\text { or budget } \\
\text { maximization, } \\
\text { striving to oc- } \\
\text { cupy the highest } \\
\text { position } \\
\text { in the league ta- } \\
\text { ble; the organi- } \\
\text { zationalstructure } \\
\text { is concentrated } \\
\text { in two areas: } \\
\text { the sports divi- } \\
\text { sion and the or- } \\
\text { ganizational di- } \\
\text { vision }\end{array}$ & $\begin{array}{l}\text { demand for re- } \\
\text { nowned players, } \\
\text { demand for re- } \\
\text { nowned trainers } \\
\text { and members } \\
\text { of the training } \\
\text { staff; the de- } \\
\text { mand of VIP cli- } \\
\text { ents related } \\
\text { to the quality } \\
\text { of the offer }\end{array}$ & 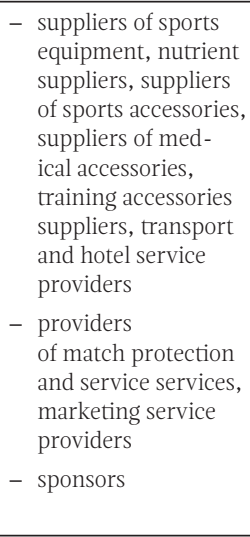 \\
\hline
\end{tabular}

Source: Own preparation. 


\section{Table 3.}

\section{Chances and government determinants of a volleyball clubs}

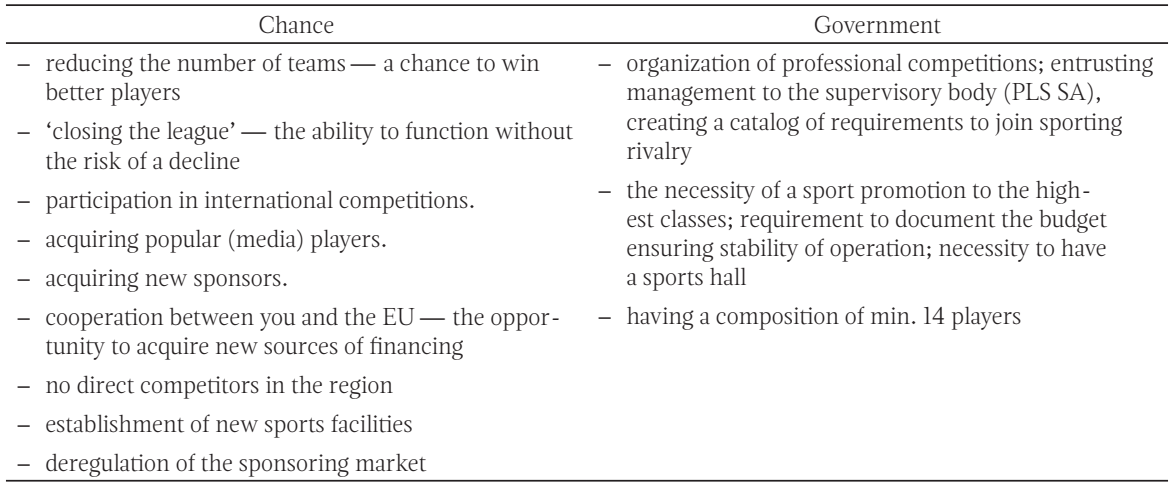

Source: Own preparation.

Scheme 1.

\section{Porters' diamond model}

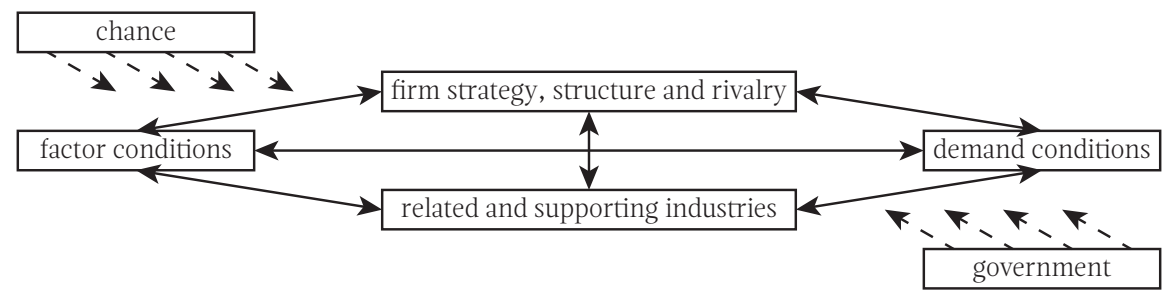

Source: Porter (1990). 
